\title{
Antioxidant Enzyme Response in Water Stress Sunflower Genotypes
}

\author{
A. Geetha*, A. Sivasankar, P. Saidaiah and Lakshmi Prayaga \\ Department of Plant Physiology, College of Agriculture, Acharya N.G Agricultural University, \\ Rajendranagar, Hyderabad (A.P.) - 500 030, India \\ *Corresponding author
}

\begin{tabular}{|c|c|}
\hline & A B S T R A C T \\
\hline $\begin{array}{l}\text { Ke y w o r d s } \\
\text { Drought, Sunflower, } \\
\text { RWC, Membrane } \\
\text { leakage, Superoxide } \\
\text { dismutase, } \\
\text { Peroxidase. }\end{array}$ & \multirow{3}{*}{$\begin{array}{l}\text { To investigate the effect of water stress on relative water content, antioxidant enzymes } \\
\text { (Superoxide Dismutase activity and Peroxidase) and membrane leakage in twelve } \\
\text { genotypes of sunflower a study was conducted during rabi, 2010-11 at College Research } \\
\text { Farm, ANGRAU, Hyderabad. Water stress was imposed at flower bud initiation stage by } \\
\text { withholding water } 20 \text { days from } 40 \text { DAS to } 60 \text { DAS, whereas, the control plots were } \\
\text { irrigated at } 10 \text { days intervals throughout the crop growth period. With increase in stress } \\
\text { duration RWC decreased in all the genotypes examined. However, genotype SH-177 } \\
\text { recovered quickly from stress by maintaining high RWC. Antioxidant enzymes i.e., } \\
\text { superoxide dismutase activity and peroxidase activity increased with stress duration and } \\
\text { age of crop. Membrane leakage increased with stress duration and age of the crop } \\
\text { indicating membrane damage is irreversible process. SH-177 for RWC, TSF-106 and DSF- } \\
104 \text { for SOD activity, DSF-111 for POX activity and ASF-107 for membrane integrity are } \\
\text { considered as promising lines to be used in drought resistance breeding programme. }\end{array}$} \\
\hline Article Info & \\
\hline $\begin{array}{l}\text { Accepted: } \\
04 \text { April } 2017 \\
\text { Available Online: } \\
10 \text { May } 2017\end{array}$ & \\
\hline
\end{tabular}

\section{Introduction}

Sunflower (Helianthus annuus L.) occupies a prominent place among oilseed crops as it contributes about $12 \%$ to the world edible oil production. In India, sunflower is cultivated in an area of $21.6 \mathrm{~m}$ ha with an annual production $1.32 \mathrm{~m}$ tones. In fact, large area under sunflower is cultivated under rainfed situation, where intermittent moisture stress is most prevalent. The decrease in productivity in oilseeds in general and in sunflower in particularly is mainly due to drought. Drought causes more than $70 \%$ reduction in biomass and seed yield in sunflower (Umashaanker, 1991). Halliwel and Gutteridge (1990) reported that in oilseed crops such as sunflower, the content of free radicals increase under stress conditions which can cause peroxidation of membrane lipids. Within a cell, superoxide dismutase (SOD) constitutes the first line of defense against ROS (Alscher et al., 2002). SOD is associated with scavenging superoxide radicals and converts them to $\mathrm{O}_{2}$ and $\mathrm{H}_{2} \mathrm{O}_{2}, \mathrm{H}_{2} \mathrm{O}_{2}$ is then detoxified by catalase or peroxidase. The simultaneous increase in the activity of these enzymes contributes to a decrease of the deleterious effects of $\mathrm{H}_{2} \mathrm{O}_{2}$ under drought stress. Cell membranes are one of the first targets of many plant stresses and it is generally accepted that the maintenance of their integrity and stability under water stress conditions is a major component of drought tolerance in plants. The degree of cell membrane injury induced by water stress may 
be easily estimated through measurements of electrolyte leakage from the cells. Researchers have linked various physiological traits of plants to drought with their tolerance mechanisms. Among which, relative leaf water contents (RWC) is best measure to level the water deficit in the plant at a specific point of time. As RWC is related to cell volume, it may closely reflect the balance between water supply to the leaf and transpiration rate (Sinclair and Ludlow, 1985). Keeping in view the above, the present investigation was taken up to study effect of drought on relative water content, electrolyte leakage, superoxide dismutase activity and peroxidase in twelve sunflower genotypes.

\section{Materials and Methods}

The experiment was laid out in (f RBD) with two factors and 12 treatments, which were replicated thrice during rabi, 2010-11 at College Research Farm, College of Agriculture, ANGRAU, Rajendranagar, Hyderabad. Control (irrigated) and water stress were used as factors. Control plots were irrigated at 10 days intervals throughout the crop growth period whereas, in stress treatment irrigation was withhold for 20 days from 40 DAS to 60 DAS. The treatments comprised of 12 genotypes. Each genotype was sown in five rows at $5 \mathrm{~m}$ length with spacing of $60 \times 30 \mathrm{~cm}$. Two to three seeds were sown per hill to achieve uniform stand. Thinning was done at two weeks after sowing to retain one seedling per hill. Recommended package of practices were followed to raise a healthy crop. In each entry, ten plants were tagged randomly. Observations were recorded at 45, 60 and 75 DAS i.e., 5 days after imposition of stress, twenty days after imposition of stress and 15 days of stress recovery period on RWC \%, electrolyte leakage, superoxide dismutase and peroxidase activities. Relative water contents (RWC) \% was measured by taking leaf disc of approximately $4 \mathrm{~cm}^{2}$ area in rectangle shape from both plants under irrigated and stressed regimes and fresh weight was measured. Discs were then dipped in glass vials containing $20 \mathrm{ml}$ of deionized water. These were left for four hours at room temperature. After four hours, leaf discs were blotted and their turgid weights were recorded. The relative water content was calculated by formula RWC $=$ [fresh weight- dry weight $/$ turgid weight - dry weight $\times 100$.

Superoxide dismutase (SOD) activity was determined as described by Misra and Fridovich (1972) with the reaction mixture contained $100 \mu \mathrm{L} 1 \mu \mathrm{mol}$ riboflavin, $100 \mu \mathrm{L}$ $12 \mathrm{~m}$ mol L-methionine, $100 \mu \mathrm{L} 0.1 \mathrm{mmol}$ EDTA (pH 7.8), $100 \mu \mathrm{L} 50 \mathrm{~m} \mathrm{~mol} \mathrm{Na}_{2} \mathrm{CO}_{3}$ $(\mathrm{pH} \mathrm{10.2)}$ and $100 \mu \mathrm{L} 75 \mu \mathrm{mol}$ nitroblue tetrazolium (NBT) in $2300 \mu \mathrm{L} 25 \mathrm{~m} \mathrm{~mol}$ sodium phosphate buffer ( $\mathrm{pH}$ 6.8), $200 \mu \mathrm{L}$ crude enzyme extract in a final volume of 3 $\mathrm{mL}$. SOD activity was assayed by measuring the ability of the enzyme extract to inhibit the photochemical reduction of NBT glass test tubes containing the mixture were illuminated with a fluorescent lamp $(120 \mathrm{~W})$; identical tubes that were not illuminated served as blanks. After illumination for $15 \mathrm{~min}$, the absorbance was measured at $560 \mathrm{~nm}$. One unit of SOD was defined as the amount of enzyme activity that was able to inhibit by $50 \%$ the photo reduction of NBT to blue formazan. Peroxidase activity was analyzed following the methodology described by Chance and Meahley (1955). Reagents used are phosphate buffer $0.1 \mathrm{M}, \mathrm{PH} 7.0$; guaiacol solution mM; $\mathrm{H}_{2} \mathrm{O}_{2} 12.3 \mathrm{mM}$. Enzyme extract for POX was prepared by first freezing the weighed amount of leaf samples $(1 \mathrm{~g})$ in liquid nitrogen to prevent proteolytic cleavage followed by grinding with extraction buffer. Brie was passed through four layers of cheese cloth and filtrate was centrifuged for $20 \mathrm{~min}$ at $15000 \mathrm{~g}$ and the supernatant was used as enzyme. $3 \mathrm{ml}$ buffer solution, $0.05 \mathrm{ml}$ guaiacol 
solution, $0.1 \mathrm{ml}$ enzyme extract and $0.03 \mathrm{ml}$ hydrogen peroxide solution was pipette out in to a cuvette. The cuvette was placed in the spectrophotometer and waited until the absorbance has increased by 0.05 . The time required was noted with the help of a stop watch in minutes to increase the absorbance by 0.1

Enzyme activity units/litre=

\section{$3.18 \times 0.1 \times 1000$}

$6.39 \times 0.1 \times d t \times 100$

Membrane leakage $\left(\mu \mathrm{A} / \mathrm{cm}^{2}\right)$ : Membrane leakage was measured using automatic conductivity meter. Single leaf disks $1 \mathrm{~cm}$ diameter were excised with a leaf punch from the fourth main stem leaf, one disc per variety per treatment from similar interveinal areas were taken, and placed into trays with individual cells containing $2 \mathrm{ml}$ double deionized water. The electrical conductivity as a measure of cell leakage was read $48 \mathrm{hrs}$ after the leaf disks were placed in double deionized water at room temperature. The resulting electrical conductivity of the ion concentration in the solution depended on the leakage from the leaf disc.

\section{Results and Discussion}

Relative water content (RWC) decreased with increase in stress duration (Table 1). Relative water content reduced with increased duration of stress. At 15 days after release of stress, genotypes varied significantly in RWC content. SH-491 followed by SH-177 under control and only SH-177 under stress recorded higher RWC \% over remaining genotypes, while, SH-177 retained highest relative water content than rest of cultivars in interaction. As per Sinclair and Ludlow, 1985 among the traits fallowing the evaluation of plant water status, leaf relative water content
(RWC) gives best idea of the level of the water deficit in the plant. As RWC is related to cell volume, when it is measured on the leaf, it may closely reflect the balance between water supply to the leaf and transpiration rate. Under water stress some genotypes maintain its RWC at par with that of non stress conditions due to production of osmoprotectants or compatible solutes (Saccharides, polyhydric compounds, amino acid and quaternary ammonium compounds). This compound reduces osmotic potential (Jha and Singh, 1997).

Antioxidant enzymes activity increases in plant cells as a response to abiotic stresses. These enzymes have important role in the defense against oxidative stress (Habibi et al., 2004). Drought stress significantly increased SOD activity throughout (Table 2) the crop period. Maximum SOD activity was observed at 15 days after release of stress (1.66 $\mathrm{eu} / 100 \mathrm{ml} /$ gram fresh weight) compared to control $(1.38 \mathrm{eu} / 100 \mathrm{ml} /$ gram fresh weight). At 15 days after stress release, treatments and genotypes exhibited significant differences in SOD activity. DSF-104 and DSF-111 under control and TSF-106 followed by DSF-104 under stress showed increased SOD activity whereas, DSF-104 maintained highest SOD activity than rest of the genotypes in interaction.

Bailly et al., (2000) reported that in sunflower, the content of superoxide dismutase (SOD) increase under drought stress condition. Halliwel and Gutteridge (1990) reported that in oilseed crops such as sunflower, the content of free radicals such as singlet oxygen, superoxide, hydrogen peroxide and hydroxyl radicals in tissue will increase under stress conditions which can cause peroxidation of membrane lipids, breakage of DNA strands and inactivate S-H group containing enzymes. 
Table.1 Mean of relative water content (RWC) (\%) of sunflower cultivars during stress and after stress influenced by moisture stress

\begin{tabular}{|c|c|c|c|c|c|c|c|c|c|c|c|c|c|}
\hline & \multicolumn{5}{|c|}{ Five days after imposition of stress } & \multicolumn{4}{|c|}{ Twenty days after imposition of stress } & \multicolumn{4}{|c|}{ Fifteen days after release of stress } \\
\hline S.No. & Genotype & Control & Stress & Mean & $\begin{array}{c}\% \\
\text { decrease } \\
\end{array}$ & Control & Stress & Mean & $\%$ decrease & Control & Stress & Mean & $\%$ decrease \\
\hline 1 & RSF-101 & 73.50 & 70.84 & 72.17 & 3.61 & 74.10 & 64.30 & 69.20 & 13.23 & 75.90 & 72.20 & 74.05 & 4.87 \\
\hline 2 & TSF-103 & 85.13 & 75.64 & 80.38 & 11.14 & 84.03 & 64.43 & 74.23 & 23.32 & 87.17 & 73.57 & 80.37 & 15.60 \\
\hline 3 & ASF-107 & 82.15 & 64.61 & 73.38 & 21.35 & 80.83 & 54.43 & 67.63 & 32.66 & 80.67 & 65.80 & 73.23 & 18.43 \\
\hline 4 & DSF-114 & 74.70 & 65.23 & 69.97 & 12.67 & 72.57 & 50.93 & 61.75 & 29.81 & 73.83 & 59.80 & 66.82 & 19.01 \\
\hline 5 & SH-177 & 91.52 & 69.93 & 80.72 & 23.58 & 86.83 & 49.50 & 68.17 & 42.99 & 90.03 & 78.23 & 84.13 & 13.11 \\
\hline 6 & DSF-104 & 72.20 & 61.73 & 66.97 & 14.50 & 75.83 & 63.10 & 69.47 & 16.79 & 88.50 & 70.23 & 79.37 & 20.64 \\
\hline 7 & RSF-106 & 81.30 & 69.93 & 75.62 & 13.98 & 79.07 & 66.13 & 72.60 & 16.36 & 75.53 & 71.23 & 73.38 & 5.69 \\
\hline 8 & DSF-111 & 83.00 & 71.40 & 77.20 & 13.98 & 79.80 & 67.53 & 73.67 & 15.37 & 80.53 & 73.03 & 76.78 & 9.31 \\
\hline 9 & RSF-107 & 78.07 & 66.20 & 72.14 & 15.20 & 83.40 & 54.80 & 69.10 & 34.29 & 85.37 & 60.80 & 73.08 & 28.78 \\
\hline 10 & ASF-104 & 79.85 & 71.20 & 75.53 & 10.83 & 79.67 & 54.00 & 66.83 & 32.22 & 80.37 & 58.60 & 69.48 & 27.08 \\
\hline 11 & TSF-106 & 80.85 & 76.32 & 78.59 & 5.60 & 79.87 & 64.50 & 72.18 & 19.24 & 79.23 & 70.73 & 74.98 & 10.73 \\
\hline \multirow[t]{2}{*}{12} & SH-491 & 88.55 & 62.33 & 75.44 & 29.61 & 90.50 & 58.07 & 74.28 & 35.84 & 91.40 & 65.17 & 78.28 & 28.70 \\
\hline & Mean & 80.90 & 68.78 & 74.84 & 14.98 & 80.54 & 59.31 & 69.93 & 26.36 & 82.38 & 68.28 & 75.33 & 17.11 \\
\hline \multicolumn{2}{|c|}{$\begin{array}{l}\text { CD at } 5 \% \text { for } \\
\text { treatments }\end{array}$} & & & 1.17 & & & & 0.84 & & & & 0.78 & \\
\hline \multicolumn{2}{|c|}{$\begin{array}{l}\text { CD at } 5 \% \text { for } \\
\text { genotypes }\end{array}$} & & & 2.88 & & & & 2.05 & & & & 1.92 & \\
\hline \multicolumn{2}{|c|}{$\begin{array}{l}\mathrm{CD} \text { at } 5 \% \text { for } \\
\mathrm{T} \times \mathrm{G}\end{array}$} & & & 4.07 & & & & 2.9 & & & & 2.72 & \\
\hline
\end{tabular}


Table.2 Mean of SOD (eu /100ml/ gram fresh weight) activity of sunflower cultivars during stress and after stress influenced by moisture stress

\begin{tabular}{|c|c|c|c|c|c|c|c|c|c|c|c|c|c|}
\hline & \multicolumn{5}{|c|}{ Five days after imposition of stress } & \multicolumn{4}{|c|}{ Twenty days after imposition of stress } & \multicolumn{4}{|c|}{ Fifteen days after release of stress } \\
\hline S. No. & Genotype & Control & Stress & Mean & $\%$ decrease & Control & Stress & Mean & $\%$ decrease & Control & Stress & Mean & $\%$ decrease \\
\hline 1 & RSF-101 & 0.88 & 1.23 & 1.06 & -40.15 & 1.16 & 1.38 & 1.27 & -18.68 & 1.34 & 1.53 & 1.44 & -14.14 \\
\hline 2 & TSF-103 & 0.70 & 1.29 & 1.00 & -84.76 & 0.97 & 1.43 & 1.20 & -47.26 & 1.28 & 1.62 & 1.45 & -26.49 \\
\hline 3 & ASF-107 & 0.83 & 1.40 & 1.12 & -68.00 & 1.16 & 1.58 & 1.37 & -36.21 & 1.48 & 1.78 & 1.63 & -20.00 \\
\hline 4 & DSF-114 & 0.60 & 1.20 & 0.90 & -100.00 & 0.83 & 1.36 & 1.09 & -64.11 & 1.26 & 1.47 & 1.37 & -16.93 \\
\hline 5 & SH-177 & 0.89 & 1.39 & 1.14 & -55.81 & 1.07 & 1.61 & 1.34 & -50.00 & 1.50 & 1.73 & 1.61 & -15.37 \\
\hline 6 & DSF-104 & 0.82 & 1.49 & 1.15 & -81.30 & 1.03 & 1.66 & 1.35 & -62.01 & 1.59 & 1.79 & 1.69 & -13.03 \\
\hline 7 & RSF-106 & 0.77 & 1.22 & 1.00 & -58.87 & 0.96 & 1.44 & 1.20 & -49.13 & 1.33 & 1.64 & 1.49 & -23.25 \\
\hline 8 & DSF-111 & 0.85 & 1.50 & 1.18 & -76.47 & 1.15 & 1.66 & 1.40 & -44.77 & 1.59 & 1.71 & 1.65 & -7.32 \\
\hline 9 & RSF-107 & 0.52 & 0.93 & 0.72 & -81.23 & 0.65 & 1.36 & 1.00 & -109.79 & 0.92 & 1.48 & 1.20 & -60.29 \\
\hline 10 & ASF-104 & 1.03 & 1.31 & 1.17 & -27.48 & 1.36 & 1.45 & 1.41 & -6.11 & 1.40 & 1.62 & 1.51 & -15.48 \\
\hline 11 & TSF-106 & 0.94 & 1.47 & 1.21 & -56.38 & 1.24 & 1.67 & 1.45 & -34.41 & 1.39 & 1.82 & 1.61 & -31.18 \\
\hline \multirow[t]{2}{*}{12} & SH-491 & 0.91 & 1.46 & 1.19 & -60.81 & 1.15 & 1.58 & 1.36 & -37.10 & 1.49 & 1.74 & 1.62 & -16.29 \\
\hline & Mean & 0.81 & 1.32 & 1.07 & -63.32 & 1.06 & 1.51 & 1.29 & -42.68 & 1.38 & 1.66 & 1.52 & -20.22 \\
\hline \multicolumn{2}{|c|}{$\begin{array}{l}\mathrm{CD} \text { at } 5 \% \text { for } \\
\text { treatments }\end{array}$} & & & 0.02 & & & & 0.01 & & & & 0.01 & \\
\hline \multicolumn{2}{|c|}{$\begin{array}{l}\mathrm{CD} \text { at } 5 \% \text { for } \\
\text { genotypes }\end{array}$} & & & 0.04 & & & & 0.03 & & & & 0.03 & \\
\hline \multicolumn{2}{|c|}{$\mathrm{CD}$ at $5 \%$ for $\mathrm{T} \times \mathrm{G}$} & & & 0.05 & & & & 0.04 & & & & 0.04 & \\
\hline
\end{tabular}


Table.3 Mean of peroxidase activity (eu/100ml/ gram fresh weight) of sunflower cultivars during stress and after stress influenced by moisture stress

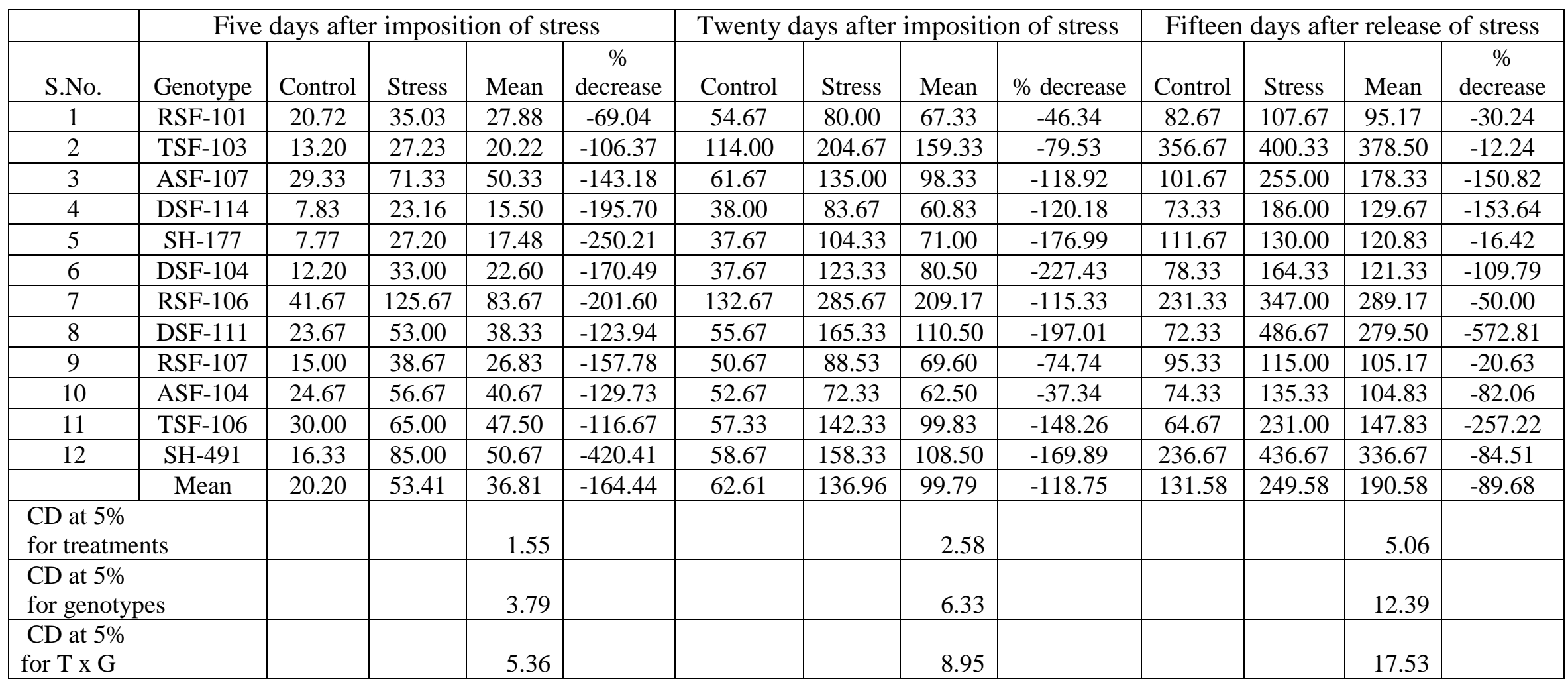


Table.4 Mean of membrane leakage $\left(\mu \mathrm{A} / \mathrm{cm}^{2}\right)$ of sunflower cultivars during stress and after stress influenced by moisture stress

\begin{tabular}{|c|c|c|c|c|c|c|c|c|c|c|c|c|c|}
\hline & \multicolumn{5}{|c|}{ Five days after imposition of stress } & \multicolumn{4}{|c|}{ Twenty days after imposition of stress } & \multicolumn{4}{|c|}{ Fifteen days after release of stress } \\
\hline S.No. & Genotype & Control & Stress & Mean & $\%$ decrease & Control & Stress & Mean & $\%$ decrease & Control & Stress & Mean & $\%$ decrease \\
\hline 1 & RSF-101 & 7.31 & 8.37 & 7.84 & -14.40 & 10.97 & 13.50 & 12.23 & -23.10 & 13.27 & 16.00 & 14.63 & -20.60 \\
\hline 2 & TSF-103 & 5.92 & 7.51 & 6.71 & -26.87 & 10.03 & 12.96 & 11.50 & -29.21 & 12.80 & 14.60 & 13.70 & -14.06 \\
\hline 3 & ASF-107 & 7.58 & 9.77 & 8.68 & -28.79 & 11.54 & 15.07 & 13.31 & -30.52 & 15.53 & 16.27 & 15.90 & -4.72 \\
\hline 4 & DSF-114 & 6.20 & 7.50 & 6.85 & -21.03 & 10.67 & 13.93 & 12.30 & -30.63 & 15.97 & 17.97 & 16.97 & -12.53 \\
\hline 5 & SH-177 & 6.42 & 10.63 & 8.53 & -65.71 & 8.83 & 11.07 & 9.95 & -25.28 & 11.23 & 12.37 & 11.80 & -10.09 \\
\hline 6 & DSF-104 & 5.60 & 6.87 & 6.23 & -22.62 & 9.20 & 9.87 & 9.53 & -7.25 & 11.73 & 12.80 & 12.27 & -9.09 \\
\hline 7 & RSF-106 & 6.02 & 7.49 & 6.76 & -24.41 & 9.43 & 10.99 & 10.21 & -16.58 & 11.97 & 13.07 & 12.52 & -9.19 \\
\hline 8 & DSF-111 & 7.41 & 8.87 & 8.14 & -19.71 & 11.80 & 13.27 & 12.53 & -12.43 & 16.93 & 19.67 & 18.30 & -16.14 \\
\hline 9 & RSF-107 & 7.26 & 9.48 & 8.37 & -30.62 & 11.70 & 13.60 & 12.65 & -16.27 & 16.77 & 19.63 & 18.20 & -17.10 \\
\hline 10 & ASF-104 & 3.90 & 6.90 & 5.40 & -76.92 & 10.37 & 13.97 & 12.17 & -34.73 & 16.03 & 19.03 & 17.53 & -18.71 \\
\hline 11 & TSF-106 & 2.90 & 4.72 & 3.81 & -62.76 & 4.87 & 8.03 & 6.45 & -65.07 & 9.03 & 10.07 & 9.55 & -11.44 \\
\hline \multirow[t]{2}{*}{12} & SH-491 & 2.34 & 6.97 & 4.65 & -197.72 & 6.03 & 8.83 & 7.43 & -46.41 & 9.47 & 11.03 & 10.25 & -16.55 \\
\hline & Mean & 5.74 & 7.92 & 6.83 & -38.07 & 9.62 & 12.09 & 10.86 & -25.69 & 13.39 & 15.21 & 14.30 & -13.54 \\
\hline \multicolumn{2}{|c|}{$\begin{array}{l}\mathrm{CD} \text { at } 5 \% \\
\text { for treatments }\end{array}$} & & & 0.06 & & & & 0.067 & & & & 0.07 & \\
\hline \multicolumn{2}{|c|}{$\begin{array}{l}\text { CD at 5\% } \\
\text { for genotypes }\end{array}$} & & & 0.14 & & & & 0.164 & & & & 0.18 & \\
\hline \multicolumn{2}{|c|}{$\mathrm{CD}$ at $5 \%$ for $\mathrm{T} \times \mathrm{G}$} & & & 0.2 & & & & 0.231 & & & & 0.26 & \\
\hline
\end{tabular}


Within a cell, superoxide dismutase (SOD) constitutes the first line of defense against reactive oxygen species associated with scavenging superoxide radicals and converting them to $\mathrm{O}_{2}$ and $\mathrm{H}_{2} \mathrm{O}_{2} \cdot \mathrm{H}_{2} \mathrm{O}_{2}$ is further detoxified by catalase or peroxidase (Alscher et al., 2002). The simultaneous increase in the activity of these enzymes contributes to a decrease of the deleterious effects of $\mathrm{H}_{2} \mathrm{O}_{2}$ under drought stress.

Peroxidase activity increased with increase in stress duration and also with age of plant (Table 3). Peroxidase activity was 53.41 $\mathrm{eu} / 100 \mathrm{ml} /$ gram fresh weight at 5 days after imposition of stress and was increased to $136.96 \mathrm{eu} / 100 \mathrm{ml} /$ gram fresh weight at 20 days after imposition of stress. At 15 days after release of stress POX activity was significantly higher in stress treatment compared to control. Genotype TSF-103 recorded highest peroxidase activity both under control and mean, while under stress DSF-111 showed higher peroxidase activity over rest of the genotypes. Puspendu Dutta and Bera (2007) reported that peroxidase activity increased under drought. Drought leads to oxidative stress through an increase in ROS such as superoxide $\left(\mathrm{O}_{2}^{-}{ }^{-}\right)$, hydrogen peroxide $\left(\mathrm{H}_{2} \mathrm{O}_{2}\right)$ and hydroxyl radicals $\left(\mathrm{OH}^{-}\right)$ which attack the most sensitive biological macromolecules like lipids, proteins and nucleic acids, cause lipid peroxidation mainly at membranes to impair their function. Plants have an enzymatic and non-enzymatic system that protects them against the damage of ROS. The anti oxidative enzymes include superoxide dismutase, peroxidase, glutathione reductase and catalase. Peroxidase and catalase detoxify the hydrogen peroxide, which accumulates in the plants under water stress. The increase in peroxidase activity of TSF-103 and DSF-111 might be due to formation of large amount of $\mathrm{H}_{2} \mathrm{O}_{2}$ during water stress and make the plant withstand drought.
Membrane leakage increased with increase in stress duration. Membrane leakage increased in stress treatments compared to control (Table 4). At 15 days after release of stress, membrane leakage increased under stress compared to control. Among genotypes TSF106 exhibited lower membrane leakage both under control and stress as well as in interaction. In interaction, ASF-107 recorded minimum reduction in membrane leakage among cultivars and maximum reduction in membrane leakage was recorded in RSF-101. Plants under water stress can exhibit changes in membrane fluidity (Sung et al., 2003). Cell membranes are important for the control of electrolyte movement in and out of the cell and also provide a stable site for the binding and catalysis of enzymes. When plants are under high-temperature induced water stress, the structure of membranes is altered, permeability increases, electrolyte leakage increases and eventually the cell dies (Wang, 1988). Cell membrane damage and the leakage of solutes have been correlated to the severity of injury (Heckman et al., 2002). High temperature tolerance in plants is attributed largely to resistance of cell membranes (Larcher, 1995) and membrane leakage has become a common method for measuring high-temperature tolerance in crop plants (Rahman et al., 2003).

Based on results obtained it can be concluded that water stress at flower bud initiation stage leads to increase in superoxide dismutase activity and peroxidase activity irrespective of genotypes whereas, RWC decreased with onset of stress and all the genotypes are able to recover its tissue hydration immediately after irrigation but damage occurring to membrane system is irreversible as measured by membrane leakage. However genotypic variation for RWC, superoxide dismutase activity, peroxidase activity and membrane leakage was significant, SH-177 for RWC, TSF-106 and DSF-104 for SOD activity, 
DSF-111 for POX activity and ASF-107 for membrane stability showed promise to perform in moisture stress conditions. These lines may be utilized in sunflower breeding aimed to develop varieties for water limited areas.

\section{References}

Alscher, R.G., et al. 2002. J. Exp. Bot., 53(327): 1331-1341.

Bailly, C., et al. 2000. Seed Sci. Res., 10(2): $35-42$.

Blum, A. 1996. Plant Growth Regulators, 20: 135-148.

Chance, B. and Meahley, A.C. 1955. Methods in enzymes assay of Catalase and Peroxidase. In: methods in enzymology - II, Academic press Inc. Publication, New York. Pp: 773-775.

Habibi, D., et al. 2004. Antioxidative enzymes in sunflower subjected to drought stress, $4^{\text {th }}$ International Crop Science Congress, Australia.

Halliwel, B. and Gutteridge, J. 1990. Free radicals and catalytic metal ions. Methods Enzymes, 186: 1-16.
Heckman, N., et al. 2002. Scientia Hort., 92: 83-186.

Jha, B.N. and Singh, R.A. 1997. Indian J. Plant Physiol., 2: 81-84.

Larcher, W. 1995. Physiol. Plant Ecol., 3rd ed., Springer.

Misra, H.P. and Fridovich, I. 1972. J. Biol. Chem., 247: 6960-6966.

Puspendu Dutta and Bera, A.K. 2007. Indian J. Plant Physiol., 12(2): 199-202.

Rahman, H., et al. 2003. Field Crops Res., 85: 149-158.

Sinclair, T.R. and Ludlow, M.M. 1985. Australian J. Plant Physiol., 12: 213217.

Sung, D.Y., et al. 2003. Trends in Plant Sci., 8: 179-187.

Umashaanker, R. 1991. Gametophytic screening techniques in identification and development of drought tolerant lines. Proceedings of National Symposium, Recent Adv. Drought Res., Dec, 10-13, kottayam, Kerala India, Pp.5.

Wang, B. 1988. Plant Physiol. Communications, 2: 12-16.

\section{How to cite this article:}

Geetha, A., A. Sivasankar, P. Saidaiah and Lakshmi Prayaga. 2017. Antioxidant Enzyme Response in Water Stress Sunflower Genotypes. Int.J.Curr.Microbiol.App.Sci. 6(5): 138-146. doi: http://dx.doi.org/10.20546/ijcmas.2017.605.017 